\title{
The Analysis of Different Customers and Employees' Perceptions from Service Quality in the Insurance Industry of Iran
}

Farveh Farivar (Corresponding author)

Attar Institute of Higher Education

No 84, Farhad 7, Farhad St, Malekabad Blvd, Mashhad, Iran

Tel: 98-915-325-5684Ｅ-mail: Farivar@attar.ac.ir

Mohammad Khanbashi

Allameh Tabatabaei University

No 12, Norozi St, Larestan St, Motahari St, Vali aser Blvd, Tehran, Iran

Tel: 98-21-8889-0607_E-mail: hamed_khanbashi@yahoo.com

Osveh Esmaeelinezhad

University of Malaysia

107-24-03, Bistari condo, Jalan 1/64 D, off Jalan Putra, K50350, kuala lumpour, Malaysia

Tel: 60-17-205-4130 E-mail: osveh@perdana.um.edu.my

Received: June 30, 2011

Accepted: August 5, 2011 Published: December 1, 2011

doi:10.5539/ijbm.v6n12p103

URL: http://dx.doi.org/10.5539/ijbm.v6n12p103

\begin{abstract}
One of the most sensitive actions taken in attracting and satisfying needs of customers is establishing a dynamic information mechanism and feedback process between organization and customers. Furthermore, the ever-increasing importance of employees in competitive environment is noticeable. Therefore, both employees and customers are concerned as sources of information that is a determinant factor in organizational success . The aim of this study is finding the differences between perception of employees and customers toward service quality in Insurance industry of Iran. The dimensions of SERCQUAL model (Tangibles, Reliability, Assurance, Responsiveness, and Empathy) were adopted to design the research questionnaire. 254 out of 420 questionnaires were completed by customers and employees. The questionnaires were analyzed by Pearson, KolmogorovSmrirnov, and T-test. The results showed that there is a significant difference between the perceptions of staffs and customers toward the Tangibles dimension while the perceptions of both groups toward other dimensions are similar.
\end{abstract}

Keywords: Service quality, Organization perception, Customer perception, Insurance industry

\section{Introduction}

In comparison to the last two years, the insurance industry of Iran has grown radically. It has reached to $\$ 4,000$ million in premiums annually. According to the insurance report of Iran (2010), insurance industry makes up 1.2 percent of GDP. In fact, this growth has happened because of two main reasons: firstly, there has been an ever-increasing understanding of the general concept of insurance among Iranian citizens and companies because of public training by mass media; secondly, Iran is moving gradually towards the liberalization of financial services. About $25 \%$ of insurance market is accounted by new private sector companies. However, there are high challenges in Iran's insurance sector which need to be solved in order to reach its full potential.

One of the most important problems is the conduct of monetary and fiscal policy. It is a difficult and long process to solve the problem related to insurance regulations. So, insurance companies spend their energy on customer relationship and service quality to increase their benefits. Quality improvement has played a key role in business today. Therefore, quality concept is categorized under organizational culture concept. It means that companies that are interested in obtaining a high level of customer value would be expected to have a culture 
supported service quality. Service quality plays a vital role in the success of organizations (Ueltschy et al., 2009). Service quality is valuable to achieve competitive advantage in the service-oriented world by distinguishing itself from competitors (Luoh \& Tsaur, 2011). In fact, service quality as a notable input to customer satisfaction can be considered a driver of customer life time value. Therefore, firm which tends to differentiate its offerings in the global arena should pay attention to understand consumer perceptions of service quality as a key element. (Ueltschy et al, 2009).

Generally, the majority of researches on service quality have been accomplished in the developed countries. Few studies have been done in the developing countries in this area. For example, in Iran most researches have been done on the customer perception of service quality. There is a huge lack of researches on employees' perception from service quality. Therefore, this study aims to fill the gap.

This research unfolds in the four steps. First, based on the literature review the SERCQUAL model has been accepted as an appropriate tool to measure the perception of customers and employees from service quality. Second, Insurance companies were highlighted as research context. Third, the reliability of this model for the selected companies as research context was examined. Finally, the data gathered by questionnaire were analyzed.

\section{Literature review}

Various efforts have been declared to improve services and processes from the perspective of customers in the private and public sectors. Most of them have focused on the satisfaction of external customer requirements. Most researches have revealed that these programs have failed to live up to initial expectations. Consequently, consultants and experts have called for a broader-based organizational focus to include the perspective of employees and their interrelationships with both managers and customers (Gowen et al, 2001).

Customers as an important factor have got more attention in customer service research (Atkins et al., 2000; Bowden, 2000). Customer centricity has been around for a long time. Drucker (1954) and Levitt (1960) have suggested that customers are the main reason for any business to exist and that customer needs are the most important thing to focus in order to be successful. However, effective customer centric service business orientation relies primarily on the employee's competences and skills to deliver service quality. The touch points of many service business activities can be the key factors that contribute to the overall service satisfaction. Employee-centric service organisations are more likely to achieve superior performance, because ultimately the production and delivery of service quality is dependent on the employees' attitudes and skills (Vella et al., 2009). The Comparison of the perspective of employees, customers, and managers should be considered unless the organization would lack vital information to use in putting together the service quality puzzle. Consideration must, therefore, be given to the attitudes and perspectives of all three critical stakeholders: those individuals who produce and manage the products or services and those who consume the organization's products or services (Gowan et al, 2011).

\subsection{Service Quality}

Globally, service quality is a critical topic in service industries which brings comparative advantage for business in the marketplace. Therefore, there is not even an iota of doubt concerning the importance of service quality as the ultimate goal of service providers throughout the world (Yunnes, 2009). A customer will judge the quality of service if its service meets his/her expectations (Grönroos, 1984; Parasuraman et al., 1985, 1988). Many scholars think that employee satisfaction with the service features may increase retention and loyalty, thus lead to increased organizational competitiveness (Yunnes, 2009). In recent years, academic researchers have focused to this subject and service quality is considered a vital measure of organizational performance (Hossain \& Leo, 2009). Service can be considered as an interactive process with certain tangible dimensions. The importance individuals attach to different dimensions of service is also subjective. When employees, customers and organizations disagreement about which dimensions of service characterize service quality, it may finally lead to inefficient service outcomes. If these attitudes fit each other, desirable service results would be more expected as completing the employee attitudes like organizational commitment and job satisfaction (Chiang, 2011).

Service quality is defined as the perception of customers toward the service element of a product (Goeldner \& Ritchie, 2006). Edvardson (1998) defined quality as satisfying needs and meeting expectations of customers, employees and owners. Therefore, knowing the various expectations and needs of these three groups and understanding they are shaped and change is important. He agreed that Service quality is often extremely depended on the relationships between customers and employees. Employees are interested in performing the kind of service activities that they individually give worth and agree with. In result, a sense of job satisfaction will be appeared by doing the activities and behaviors that they personally worth and take responsibility for. Studies have proved a positive connection between job satisfaction and the perception of employees about service (Chiang, 2011). 
Tornow and Wiley (1991) Showed that there is a direct relationship between customer satisfaction and the attitudes of employees and on the other hand, there is a connection between them and organization practices. In addition, they proved that employee attitudes not only affect customer satisfaction but organizational effectiveness. Although there are considerable marketing research to improve conceptual models and evaluation of methodologies for service quality (Berry \& Parasuraman, 1997; Schneider \& Bowen 1985), few research consider if employees and customers really agree on the service quality which provided. Few studies have examined the correlation analysis which doesn't show the direction and differences between the agreement of employees and customers toward service quality (Gowan et al, 2011).

Studies have shown that job satisfaction is positively related to employee perceptions of service quality and customer ratings of service quality. This idea is at the heart of the service-profit-chain theory developed by Heskett et al. (1994), which suggests that the firm's financial performance is derived from customer satisfaction, which is derived from employee performance, which, in turn, is derived from employee satisfaction. ( Snipes et al., 2009).

Previous research has indicated that high levels of customer satisfaction are related to the service quality provided through customer interactions. The service profit chain specifically identifies a relationship between employee satisfaction, service quality and customer satisfaction. Service quality has formed a nucleus of research incorporating many dimensions of service outcome and the parameters for achieving these outcomes: costs, profitability, customer's satisfaction, customer retention, and service guarantee; corporate marketing and financial performance (Kumar et al., 2008).

In the last three decades, service quality has been a common topic which attempts to identify that service quality is defend" corresponding to the customers' expectations and satisfy their needs and requirements. Researches about service quality are interested in the issue of measurement. Different models have been designed to determine the service quality level. For example, Gronroos (1984) counted two dimensions to determine service quality level: functional quality and technical quality and he classified the perception of customers into three groups: favorable, unfavorable, and neutral. On the base of same attitude, Lehtinen et al (1991) argued that service quality has a three-dimensional concept including: physical, interactive, and corporate qualities and they mentioned these three dimensions affected each other. They, also, compared their model to Gronroos' model and they argued that Gronroos' model is more abstracted. Nevertheless, many researchers have chosen SERCQUAL instrument as measuring service quality (kang \& James, 2004).

Between 1985 and 1988, Parasuraman, Zeithaml, and Berry considered service quality as a type of attitude. They defined service quality as the difference of customer perceptions of service being presented by the given industry with the customer expectations of excellent service within the organization. Berry (1988) implied that the distance between the expectations and perceptions of the real level of performance influence the customer's evaluation of overall service quality. They developed 'SERVQUAL' which the best applicable model of service quality that compares performance and expectation for a series of linked attributes. Service quality instrument comprises 22 items based on five dimensions used by costumers when evaluating service quality without regard to the kind of customer service. The dimensions include:(1) Tangibles: The appearance of physical facilities, equipment, and personnel ;(2) Reliability: The ability to perform the promised service dependably and accurately; (3) Responsiveness: The willingness to help customers and provide prompt service; (4) Assurance: The knowledge and courtesy of employees and their ability to inspire trust and Confidence; and (5) Empathy's and individualized attention to customers (Jiang \& Klein, 2002).

\section{Research Hypotheses, Data analysis and Findings}

In this study, the research methodology was survey and data were gathered by questionnaire. The main hypothesis is:

Hypothesis 1: The average of employees' perceptions toward the service quality is higher than the average of customers' perceptions

According main hypothesis and elements of SERVQUAL model 5 alternative hypotheses formed:

Hypothesis 2: The average of employees' perceptions toward the tangibles is higher than the average of customers' perceptions

Hypothesis 3: The average of employees' perceptions toward reliability is higher than the average of customers' perceptions

Hypothesis4: The average of employees' perceptions toward assurance is higher than the average of customers' perceptions 
Hypothesis 5: The average of employees' perceptions toward responsiveness is higher than the average of customers' perceptions

Hypothesis 6: The average of employees' perceptions toward empathy is higher than the average of customers' perceptions

The SERVQUAL model was adopted to design the research questionnaire. This model contains 5 dimensions: Tangibles, Reliability, Assurance, Responsiveness, and Empathy and each of this dimensions includes various variables. The questionnaire was consisted of 22 questions on a 7-point scale from strongly agreement (7) to strongly disagreement (1). In addition, two more control questions were used to make questionnaire more precise. The reliability of questionnaire was determined by a pre test of 40 respondents that the Cronbach Alpha was 0/86 so the reliability of questionnaire was acceptable.

Of the 70 questionnaires gave to employees, 51 were completed and returned for this study. 203 customers also answered to the questionnaires that represent a respond rate of 58\%. Data were analyzed through three different tests. First, Pearson Correlation Coefficient for investigating the correlation between general concept of services quality and the other defined dimensions. Then, for investigating if there is a data normal distribution, Kolmogorov- Smrirnov test have done and finally, the results of comparing mean scores of perceptions were analyzed by T-test.

\subsection{Pearson Correlation Coefficient}

To make sure if there is any meaningful relationship between general concept of service quality and every other dimension, Pearson Correlation Coefficient have done and the results are as follows:

\section{Insert table 1 - here}

As is evident from the above table, the estimated P-value for each variable in this study is less than the significance level of $0 / 01$. Thus, it can be said that there is a direct relationship between the five dimensions of SERVQUAL model and the concept of service quality. In other words, these dimensions were suitable indicators for the variables of service quality in this study.

\subsection{Statistical Hypotheses}

$\mathrm{H} 0$ : there is no a normal distribution in relevant samples

H1: there is a normal distribution in relevant samples

Insert table 2 - here

According to the above table, the two-tailed significance level for each group is more than $0 / 05$. Also, the critical value for Kolmogorov- Smrirnov test is less than the critical value 1/96. Therefore, at the confidence level of $95 \%$, it can be said that there is a normal distribution in the sample and $\mathrm{H} 1$ is acceptable.

\subsection{Testing of Study'S Hypotheses}

\section{Main hypothesis:}

H0: there is not a significant difference between the employees and customers' perceptions toward the service quality of the organizationH1: there is a significant difference between the employees and customers' perceptions toward the service quality of the organization

H0: $\left\{\begin{array}{l}\mu_{1}=\mu_{2} \\ \text { H1: } \\ \mu_{1} \neq \mu_{2}\end{array}\right.$

Insert Table 3 - here

Since the estimated two-tailed significance level is more than $0 / 05$, the null hypothesis is accepted. This means that there is no significance difference between the staffs' and customers' perceptions toward service quality. In addition, the results of t-test for alternatives hypotheses are shown in the table (4).

\section{Insert Table 4 - here}

According table above, since the amount of two-tailed significance level is less than $0 / 05$, there is a significance different between the perception of employees and customers toward Tangibles while the two-tailed significance level for Reliability, Assurance, Responsiveness, and Empathy dimensions are more than 0/05 so it can be said that at the confidence level of 0/95 there is no considerable difference between employees' and customers' perception toward these dimensions. In the other words, the second hypothesis is accepted while the third, fourth, fifth, sixth cannot be accepted. 


\section{Conclusion}

Analyzing shows the average of both groups toward service quality is just slightly above the average and this means that it is still far from desired level. However, insurance industry in Iran has grown substantially in recent years. Moreover, it is important to notice that despite the perception of both groups are relatively the same, employees are aware of weaknesses but employees mentioned feedback forms only are given to customers. Then, employees strongly felt that they have not been considered as much as their roles are important and vital in firms' success. To solve this problem, companies have to do more surveys on employees' attitude toward service quality and encourage or persuade them by materialistic methods and spiritual ones as well. For example, some kinds of rewards should be considered for those staff who well-managed in treating the customers. Generally speaking, evaluating service quality brings better understanding how various dimensions affect all service quality process which results in both the better allocation of resources and better services. Then, further efforts should continue to understand the concept of service quality in Iran.

\section{References}

Atkins, C. R., Dykes, P., Hagerty, J., \& Hoye, J. (2002). How customer performance partnerships can sharpen your competitive edge. The Journal for Quality and Participation, 25(3), pp 22-25.

Berry, L., Parasuraman, A., \& Zeithaml, V. (1988). The service quality puzzle. Business Horizons, 31, 35-43. http://dx.doi.org/10.1016/0007-6813(88)90053-5

Bowden, P. (2000). Delivering organizational excellence by employee values management. Total Quality Management, 11, 636-640. http://dx.doi.org/10.1080/09544120050007995

Chiang, F.F.T., \& Birtch, T. A. (2011). Reward climate and its impact on service quality orientation and employee Attitudes. International Journal of Hospitality Management, 30, 3-9. http://dx.doi.org/10.1016/j.ijhm.2010.03.007

Edvardsson, B. (1998). Research and concepts: Service quality improvement. Managing Service Quality, 8 (2), 142-149. http://dx.doi.org/10.1108/09604529810206972

Hossain, M., \& Leo, S. (2009). Customer perception on service quality in retail banking in Middle East: the case of Qatar. International Journal of Islamic and Middle Eastern Finance and Management, 2(4). http://dx.doi.org/10.1108/17538390911006386

Iran Insurance Report Q2. (2010). ID: I59E20FCE06EN. [Online] Available: http://marketpublishers.com/r/159E20FCE06EN.html (2 May 2011)

Gowan, M., Seymour, J., barreche, S., \& Lackey, C. (2001). Service quality in a public agency: same expectations but different perceptions by employees, managers, and customers. Journal of Quality Management, 6, 275-291. http://dx.doi.org/10.1016/S1084-8568(01)00040-2

Gronroos, C. (1984). A service quality model and its marketing implications. European Journal of Marketing, 18(4), 36-44. http://dx.doi.org/10.1108/EUM0000000004784

Jiang, J.J., \& Klein, G. (2002). Measuring Information System Service Quality: Servqual from the Other Side. MIS Quarterly, 26 (2), 145-166. http://dx.doi.org/10.2307/4132324

Kang, G.D., \& James, J. (2004). Service quality dimensions: an examination of Gro“ nroos's service quality model. Managing Service Quality, 14, 266-277. http://dx.doi.org/10.1108/09604520410546806

Kumar, V., Smart, P. A., Maddern, H., \& Maull, R.S. (2008). Alternative perspectives on service quality and customer satisfaction: the role of BPM. International Journal of Service Industry Management, 19(2), 176-187. http://dx.doi.org/10.1108/09564230810869720

Lehtinen, U., \& Lehtinen, J. R. (1991). Two approaches to service quality dimensions. Service industries Journal, 11(30), 287-303. http://dx.doi.org/10.1080/02642069100000047

Luoh, H.F., \& Tsaur, S.H. (2011). Customers' perceptions of service quality: Do servers' age stereotypes matter?. International Journal of Hospitality Management, 30, 283-289. http://dx.doi.org/10.1016/j.ijhm.2010.09.002

Parasuraman, A., Zeithaml, V. A., \& Berry, L. L. (1985). A conceptual model of service quality and its implication for future research. Journal of Marketing, 49, 41-50. http://dx.doi.org/10.2307/1251430

Parasuraman, A., Zeithaml, V. A., \& Berry, L. L. (1988). SERVQUAL: A multiple-item scale for measuring consumer perceptions of service quality. Journal of Retailing, 64(1), 12-40.

Schneider, B., \& Bowen, D. (1985). Employee and customer perceptions of services in banks: replication and extension. Journal of Applied Psychology, 70(3), 423-433. http://dx.doi.org/10.1037/0021-9010.70.3.423

Tornow, W., \& Wiley, J. (1991). Service quality and management practices: a look at employee attitudes, 
customer satisfaction, and bottom line consequences. Human Resource Planning, 14, 105-115. http://dx.doi.org/10.1108/02621719610107827

Snipes, R.L., Oswald, S.L., LaTour, M., \& Armenakis, A.A. (2005). The effects of specific job satisfaction facets on customer perceptions of service quality: an employee-level analysis. Journal of Business Research, 58, 1330 - 1339. http://dx.doi.org/10.1016/j.jbusres.2004.03.007

Ueltschy, L.C., Laroche, M., Zhang, M., Cho, H., \& Yingwei , R. (2009). Is there really an Asian connection? Professional service quality perceptions and customer satisfaction. Journal of Business Research, 62(10), 972-979. http://dx.doi.org/10.1016/j.jbusres.2008.03.003

Vella, P.J., Gountas, J \& Walker, R. (2009). Employee perspectives of service quality in the supermarket sector. Journal of Services Marketing, 23(6), 407-421. http://dx.doi.org/10.1108/08876040910985870

Yunus, N.K.Y., Ismail, A., Juga, Z.R., \& Ishak, S. (2009). Service quality dimensions, perceive value and customer satisfaction: ABC relationship model testing. IBEJ, 2(2), 1-18, ISSN 1985-2126.

Table 1. Relationship between General Concept of Service Quality and Dimension of SERVQUAL Model

\begin{tabular}{|l|c|c|}
\hline Dimensions & Pearson correlation & Significance level (two-tailed) \\
\hline Tangibles & $0 / 637$ & $0 / 000$ \\
\hline Reliability & $0 / 818$ & $0 / 000$ \\
\hline Responsiveness & $0 / 820$ & $0 / 000$ \\
\hline Assurance & $0 / 776$ & $0 / 000$ \\
\hline Empathy & $0 / 823$ & $0 / 000$ \\
\hline
\end{tabular}

Table 2. Normal Distribution in the Sample

\begin{tabular}{|l|l|c|c|}
\hline \multicolumn{2}{|l|}{ Research samples } & Employees' samples & Customers' samples \\
\hline Numbers & 51 & 203 \\
\hline \multirow{2}{*}{$\begin{array}{l}\text { Normal } \\
\text { parameter }\end{array}$} & Average & $82 / 5882$ & $80 / 5862$ \\
\cline { 2 - 4 } & Standard deviation & $9 / 21125$ & $7 / 04906$ \\
\hline \multirow{3}{*}{ Differences } & Absolute & $0 / 096$ & $80 / 5862$ \\
\cline { 2 - 4 } & Positive & $0 / 076$ & $0 / 967$ \\
\cline { 2 - 4 } & Negative & $-0 / 684$ & $80 / 5862$ \\
\hline \multicolumn{2}{|l|}{ Kolmogorov- Smrirnov } & $0 / 684$ & $0 / 967$ \\
\hline \multicolumn{2}{|l|}{ Significance level (two-tailed) } & $0 / 738$ & $0 / 307$ \\
\hline
\end{tabular}

Table 3. The Result of T-test for Main Hypothesis

\begin{tabular}{|c|c|c|c|c|}
\hline $\begin{array}{c}\text { The average of } \\
\text { employees' } \\
\text { perceptions }\end{array}$ & $\begin{array}{c}\text { The average of } \\
\text { customers' } \\
\text { perceptions }\end{array}$ & T-value & $\begin{array}{c}\text { Degree of } \\
\text { freedom }\end{array}$ & Significance level \\
\hline $3 / 76$ & $3 / 66$ & $-1 / 811$ & 252 & $0 / 071$ \\
\hline
\end{tabular}

Table 4. The Results of T-test for Alternatives Hypotheses

\begin{tabular}{|l|c|c|c|c|c|}
\hline $\begin{array}{c}\text { SERVQUAL } \\
\text { model } \\
\text { Dimensions }\end{array}$ & $\begin{array}{c}\text { The average } \\
\text { of employees, } \\
\text { perceptions }\end{array}$ & $\begin{array}{c}\text { The average } \\
\text { of customers' } \\
\text { perceptions }\end{array}$ & T-value & $\begin{array}{c}\text { Degree of } \\
\text { freedom }\end{array}$ & $\begin{array}{c}\text { Significance } \\
\text { level }\end{array}$ \\
\hline Tangibles & $3 / 96$ & $3 / 38$ & $-8 / 822$ & 252 & $0 / 00$ \\
\hline Reliability & $3 / 81$ & $3 / 79$ & $-0 / 324$ & 252 & $0 / 746$ \\
\hline Assurance & $3 / 76$ & $3 / 87$ & $1 / 798$ & 252 & $0 / 073$ \\
\hline Responsiveness & $3 / 72$ & $3 / 76$ & $0 / 57$ & 252 & $0 / 569$ \\
\hline Empathy & $3 / 54$ & $3 / 49$ & $-0 / 662$ & 252 & $0 / 508$ \\
\hline
\end{tabular}

